\title{
Depth Variation of the Lithosphere beneath Garoua Rift Region (Cameroon Volcanic Line) Studied from Teleseismic P-Waves
}

\author{
Serge H. Kengni Pokam ${ }^{1,2}{ }^{*}$, Charles T. Tabod ${ }^{1,2}$, Eric N. Ndikum ${ }^{1,3}$, Alain P. Tokam Kamga1, \\ Blaise P. Pokam Gounou ${ }^{1}$
}

${ }^{1}$ Department of Physics, Faculty of Science, University of Yaounde I, Yaounde, Cameroon

${ }^{2}$ Department of Physics, Faculty of Science, The University of Bamenda, Bamenda, Cameroon

${ }^{3}$ Department of Physics, HTTC Bambili, The University of Bamenda, Bamenda, Cameroon

Email: *pokamhugue@yahoo.fr

How to cite this paper: Pokam, S.H.K., Tabod, C.T., Ndikum, E.N., Kamga, A.P.T. and Gounou, B.P.P. (2019) Depth Variation of the Lithosphere beneath Garoua Rift Region (Cameroon Volcanic Line) Studied from Teleseismic P-Waves. Open Journal of Earthquake Research, 8, 116-131. https://doi.org/10.4236/ojer.2019.82008

Received: October 17, 2018

Accepted: May 27, 2019

Published: May 30, 2019

Copyright $\odot 2019$ by author(s) and Scientific Research Publishing Inc. This work is licensed under the Creative Commons Attribution International License (CC BY 4.0).

http://creativecommons.org/licenses/by/4.0/

\begin{abstract}
Teleseismic events have been selected from a database of earthquakes with three components which were recorded between February 2005 and January 2007 by five seismic stations across the Garoua rift region which constitutes a part of the Cameroon Volcanic Line (CVL). The iterative time deconvolution performed by [1] applied on these teleseismic events, permitted us to obtain P-receiver functions. The latter were subsequently inverted in order to obtain S-wave velocity models with respect to depth which were then associated to the synthetic receiver functions. This made it possible to explain the behavior of the wave and the medium through which they traveled. The main results obtained indicate that: (1) The lithosphere appears to be thin in its crustal part with a mean Moho depth of $28 \mathrm{~km}$ and S wave velocity of $3.7 \mathrm{~km} / \mathrm{s}$. (2) In its mantle part, the lithosphere is thick in nature having a thickness that varies between $42 \mathrm{~km}$ and $67.2 \mathrm{~km}$. The greatest depth is noticed towards the center located around Garoua while the least depth corresponds to a location around Yagoua in the North. The Low velocity zone which makes it possible to determine the depth of the lithosphere was seen to have a thickness which varies between $42 \mathrm{~km}$ and $118.8 \mathrm{~km}$. (3) The synthetic receiver functions associated to shear velocity models reveal that, on one hand the wave has really undergone a conversion and multiple conversions such that the existing Ps phase and subsequent reverberations PpPs and PpSs have mean times of $3.7 \mathrm{~s}$, $11 \mathrm{~s}$ and $17.6 \mathrm{~s}$ respectively. On the other hand, they reveal an attenuation shown by the decrease in the amplitude of the aforementioned phases along a South-North direction in the Garoua rift.
\end{abstract}




\section{Keywords}

Teleseismic, Receiver Functions, Depth of Lithosphere, Low Velocity Zone, Garoua Rift Region

\section{Introduction}

The Garoua rift region is the continuation of the Northern section of Cameroon Volcanic Line and the part of the large Benue trough which, is situated between the latitude $8^{\circ}$ and $11^{\circ}$ North and longitudes $13^{\circ}$ and $16^{\circ}$ East. It is bounded to the west by the Federal Republic of Nigeria, to the North by the Mandara Mounts and to the south by the Adamawa plateau (Figure 1).

Structural and geological studies by [2] and [3] show that the Garoua basin is an E-W to N120 trending trough infilled by Middle to Upper Cretaceous marine sandstones. These sediments have also been described by [4] and [5]. The Garoua sandstone series overlap an approximately E-W trending trough called the Tcheboa trough, similar to the Figuil, Hama-koussou and Mayo-Oulo basins [6] [7]. The whole region of the Garoua basin presents outcrops of sandstone and intrusive granites, which form the basement complex below the sediments, and intrusive diorites along the Poli-Lere axis [8]. Some hypovolcanic dykes are also found within the Garoua sandstones. The basaltic lavas (Figure 1) found here are similar to those of the Cameroon Volcanic Line [9]. The basin is limited by normal faults which outcrop on its northern and southern borders [3] [8] [10].

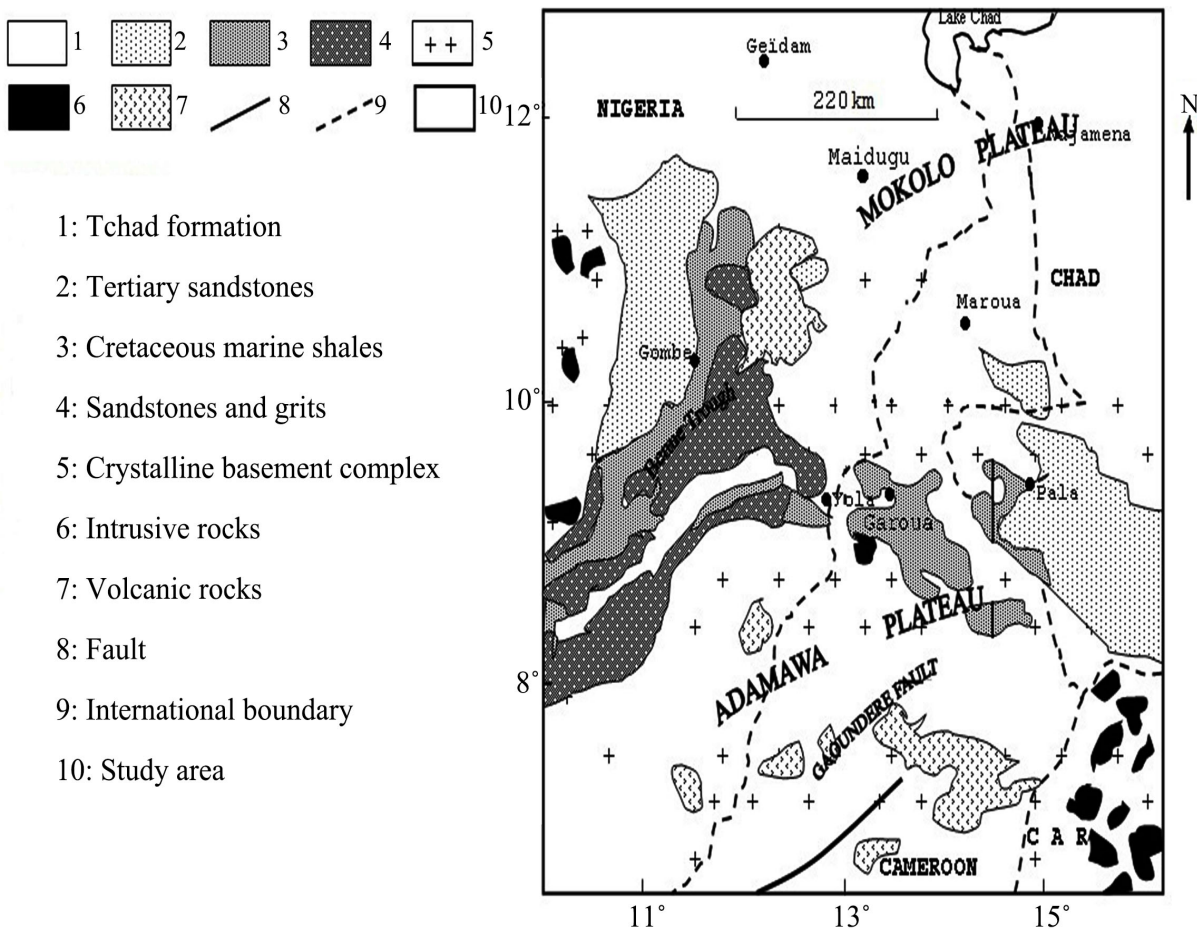

Figure 1. Simplify geological map of Garoua rift region (modified after [11]). 
Some geophysical works have been carried out in the Garoua rift region and particularly in the Garoua basin area. The regional structural setting of the Garoua Basin is characterized by three major normal faults striking mainly in the NW-SE to NNE-SSW direction [12]. The continental crust underneath the basin (about $24 \mathrm{~km}$ ) is thinner than the normal crust, but may be a little thicker to the east. This thinning of the crust is due to extensional regional stress and the uplift of the Asthenosphere is as a consequence and this result from an isostatic compensation. This leads to an average sedimentary pile thickness of about $6 \mathrm{~km}$ from results obtained by [11] and [12]. This thinning is probably due to the extensional process of basin formation in the Cretaceous. The Moho is found to be uplifted in the basin, and would be the result of this extension and the associated thermal and isostatic compensation. [13] reveal a crustal thinning in some parts of the Central African Shear Zone (CASZ) including the Garoua basin. Other gravity studies by [14] [15] and [16] suppose an uplifting of the upper mantle resulting in an abnormally thin continental crust. The continental crust is thinner below the trough and its associated basins ( $15 \mathrm{~km}$ to $24 \mathrm{~km}$ thick) than the normal $33 \mathrm{~km}$ [13] [17] and [18]. [19] used records of quarry blasts (active source seismic data) on a North-South profile across the Adamawa plateau performed a study of the crustal structure associated with the Adamawa plateau and the Garoua Rift. This study revealed a considerable thinning of the Crust when moving south of the Adamawa Plateau towards the Garoua Rift region. The Crust thins from $33 \mathrm{~km}$ south of the Adamawa Plateau to about $23 \mathrm{~km}$ at the Garoua rift region. The crustal thickness of $22 \mathrm{~km}$ obtained by [18] varies as a function of the density contrast between the lower crust and the upper mantle. Recently gravity data acquired from Earth Gravitational Model (EGM-2008) were analyzed by [20] to estimate the sedimentary thickness, extension and shape of the Garoua Basin, North Cameroon. Two dimensional (2-D) forward modeling of the gravity data using Grav2dc v2.06, which uses the Talwini's algorithm was conducted along three profiles oriented NE-SW, NNE-SSW and WNW-ESE to verify the lateral variations of the sediment pile beneath these profiles. Accordingly, Garoua is made up of alternating succession of horsts and grabens bounded to the north and south by normal faults infilled with sedimentary rocks underlain by a rifted basement. The gravity models suggest an average thickness of sediments of $9 \mathrm{~km}$ with a graben-shaped and extents over $80 \mathrm{~km}$. [21] used the surface waves tomography to indicate that the mantle beneath the CVL is characterized by slow seismic wave velocity and the lithosphere-asthenosphere boundary is shallower than $100 \mathrm{~km}(\sim 60 \mathrm{~km})$. [22] from the receiver functions technic applied on the Raleigh waves have shown that, the crust is thin with the mean thickness of $25.5 \mathrm{~km}$ for an average crustal S-wave velocity of $3.4 \mathrm{~km} / \mathrm{s}$. [23] used body wave tomography to image the mantle seismic structure beneath Cameroon using data from the 2005-2007 CBSE network. They found that a continuous low velocity zone $(\delta \mathrm{Vs}=-2 \%$ to $-3 \%)$ underlies the entire CVL to a depth of at least $300 \mathrm{~km}$ and attributed this to a thermal anomaly of at least 280 
K. [24] stacked the receiver functions using a 3-D velocity model, revealing Ps conversions from the mantle transition zone discontinuities at depths of $\sim 410$ and $660 \mathrm{~km}$. Results yield a nearly uniform transition zone thickness $(251 \pm 10$ $\mathrm{km}$ ) that is similar to the global average, implying that any thermal anomalies in the upper mantle beneath the CVL do not extend as deep as the transition zone. [25] stacked receiver functions to study crustal structure using earthquakes recorded by the Cameroon Broadband Seismic Experiment. In regions of the CVL unaffected by the Cretaceous extension associated with the breakup of Gondwana (e.g. the Garoua rift), Vp/Vs ratios are markedly low (network average 1.74) compared to hot spots elsewhere, providing no evidence for either melt or cooled mafic crustal intrusions due to CVL magmatism. The character of P-to-S conversions from beneath the CVL also indicates that lower-crustal intrusions (often termed underplate) are not present beneath the region. Although the previous investigations of the lithosphere where done with artificial seismic sources which led to interpretations leaning on inappropriate velocity models [13] [17] [18] [19] or with potential methods [11] [14] [15] [16] [20] that present a low resolution power or studied the crust using active sources [19] on one hand. The other investigations provided important measurements and high-resolution image of the lithospheric structure in Cameroon using the stack method of the receiver functions resulting from the surface waves [25] or focused mainly on the mantle [23] and [24] in other hand. In this present work, we will come out a 1-D velocity model of S-waves of the lithosphere from the inversion of the $\mathrm{P}$-waves receiver functions having the properties to propagate beyond the crust. This shear wave velocity models could also provide information regarding its structure.

\section{Data and Methodology}

\subsection{Data}

The data used in this study consist of the earthquakes recorded by 32 portable broad-band seismometers installed across the country between January 2005 and February 2007 by the Cameroon Broadband Seismic Experiment. The data were collected by a team of geoscientist from the University of Yaounde I and the Institute of Geological and Mining Research-Cameroon in partnership with researchers from Pen State University in the United State of America. The seismic network comprised 5 broadband stations (Table 1) equipped with a broad-band seismometer (Guralp CMG-3T or Streckeisen STS-2), a 24-bit Reftek digitizer and a GPS (Global Positioning System) clock (Figure 2).

Data were recorded continuously at a rate of 40 samples per second. In the study area, two stations (red color) were installed in 2005 January and operated during 2 years; the remaining four stations (yellow color) operated only during the second year of the experiment. The station spacing during the second year (2006) of operation was about 50 to $150 \mathrm{~km}$ [26]. From the earthquake data recorded, the teleseismic events that occurred at epicentral distances between $30^{\circ}$ 
and $95^{\circ}$ with magnitudes $M_{B} \geq 5.5$. have been selected (Table 2) to construct the S-wave velocity models beneath the different stations of the Garoua rift by application of the P-wave receiver functions technique.

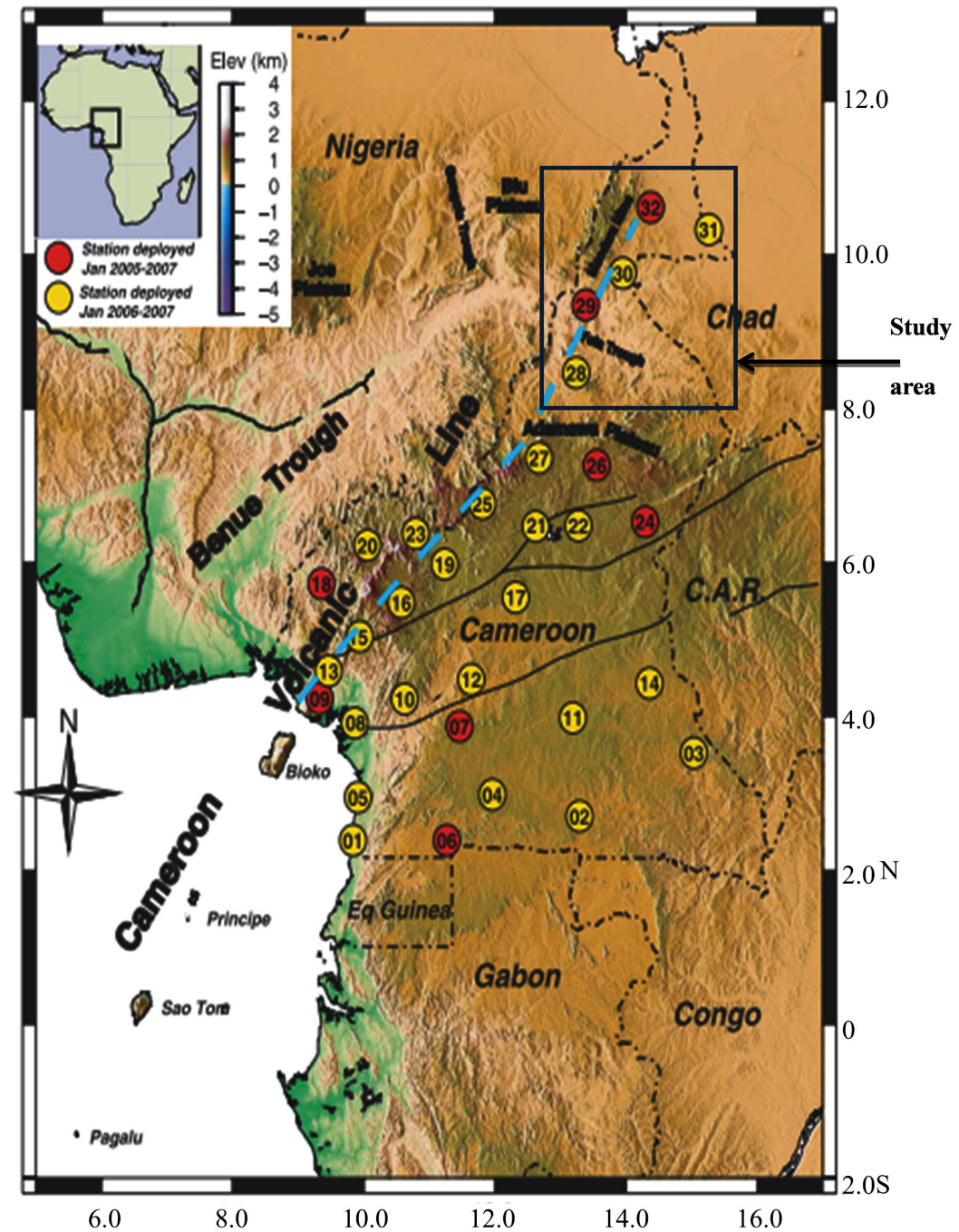

Figure 2. Colour elevation map showing seismic station locations and shear zones. The circled numbers refer to station codes, for example, 28 refers to station CM28 and the blue rectangle represents the study area (Modified after [22]).

Table 1. Characteristics of the different stations which recorded the teleseismic events.

\begin{tabular}{cccccc}
\hline $\begin{array}{c}\text { Station } \\
\text { code }\end{array}$ & Town & $\begin{array}{c}\text { Installation } \\
\text { year }\end{array}$ & Latitude $\left(^{\circ}\right)$ & Longitude $\left(^{\circ}\right)$ & $\begin{array}{c}\text { Elevation } \\
(\mathrm{km})\end{array}$ \\
\hline CM28 & Poli & 2006 & $9: 07$ & 8.45 & 0.48 \\
CM29 & Garoua & 2005 & $10: 42$ & 9.35 & 0.26 \\
CM30 & Figuil & 2006 & $10: 42$ & 9.35 & 0.26 \\
CM31 & Yagoua & 2006 & $9: 24$ & 9.75 & 0.29 \\
CM32 & Maroua & 2005 & $10: 05$ & 10.33 & 0.33 \\
\hline
\end{tabular}


Table 2. Events with magnitude $M_{B} \geq 5.5$ used for the study.

\begin{tabular}{ccccccc}
\hline $\begin{array}{c}\text { Event date } \\
\mathrm{mm} / \mathrm{dd} / \mathrm{yy}\end{array}$ & $\begin{array}{c}\text { Event time } \\
\text { h:min:s }\end{array}$ & Latitude $\left({ }^{\circ}\right)$ & Longitude $\left({ }^{\circ}\right)$ & Depth $(\mathrm{km})$ & Magnitude & $\begin{array}{c}\text { Epicentral } \\
\text { distance }\left({ }^{\circ}\right)\end{array}$ \\
\hline $10 / 20 / 05$ & $21: 40: 04: 01$ & 38.152 & 26.751 & 10 & 5.5 & 33.1 \\
$12 / 05 / 05$ & $12: 19: 56: 06$ & -6.224 & 29.83 & 22 & 6.4 & 21 \\
$12 / 09 / 05$ & $23: 30: 23: 09$ & -6.176 & 29.709 & 10 & 5.5 & 20.9 \\
$01 / 08 / 06$ & $11: 34: 55: 06$ & 36.311 & 23.212 & 66 & 6.5 & 30.2 \\
$02 / 22 / 06$ & $22: 19: 07: 01$ & -21.324 & 33.583 & 11 & 6.5 & 34.5 \\
$03 / 15 / 06$ & $14: 19: 48: 07$ & -21.136 & 33.719 & 10 & 6.5 & 33.9 \\
$09 / 17 / 06$ & $07: 30: 11: 00$ & -17.694 & 41.827 & 10 & 5.5 & 37 \\
$09 / 24 / 06$ & $22: 56: 21: 07$ & -17.737 & 41.814 & 10 & 5.6 & 37.5 \\
\hline
\end{tabular}

\subsection{Methodology}

\subsubsection{Computation of the Receiver Functions}

The treatment of the teleseismic is based on the receiver function method. The receiver functions are time series, computed from three component seismograms, which show the relative response of earth structure near the receiver. They are generated by the time domain iterative deconvolution method of [1], applied to seismograms constituted to the North, East and Vertical components which are then rotated into radial, transverse and vertical components respectively which can be used to image velocity contrasts across discontinuities.

The computation of the receiver functions began with a visual inspection in order to confirm the presence of the signal. Then after, if the wave forms which appear on the three components of the seismogram can be identified (Figure 3), then the selected waveforms were decimated to 10 samples per second, windowed between $20 \mathrm{~s}$ and $140 \mathrm{~s}$ after the leading $\mathrm{P}$ arrival, de-trended, tapered and high pass filtered above $50 \mathrm{~s}$ to remove low-frequency, instrumental noise.

Radial and transverse receiver functions were then obtained from the filtered traces by rotating the original horizontal components around the corresponding vertical component into the great circle path (Figure 4), and deconvolving the vertical component from the radial component through the iterative time domain déconvolution procedure of [1], with 200 iterations using the Gaussian a = 2.5 corresponding at to the frequency $1.2 \mathrm{~Hz}$ because, it helps to discriminate gradational transitions from sharp discontinuities in the receiver structure under the station [27].

To complete the estimation of the receiver functions, the recovery percentage of the original radial waveform was evaluated from the rms misfit between the original radial waveform and the convolution of the radial receiver function with the original vertical component [26]. Events that were recovered to less than 85 percent were rejected. The remaining waveforms were visually inspected for coherence and stability (Figure 5). 


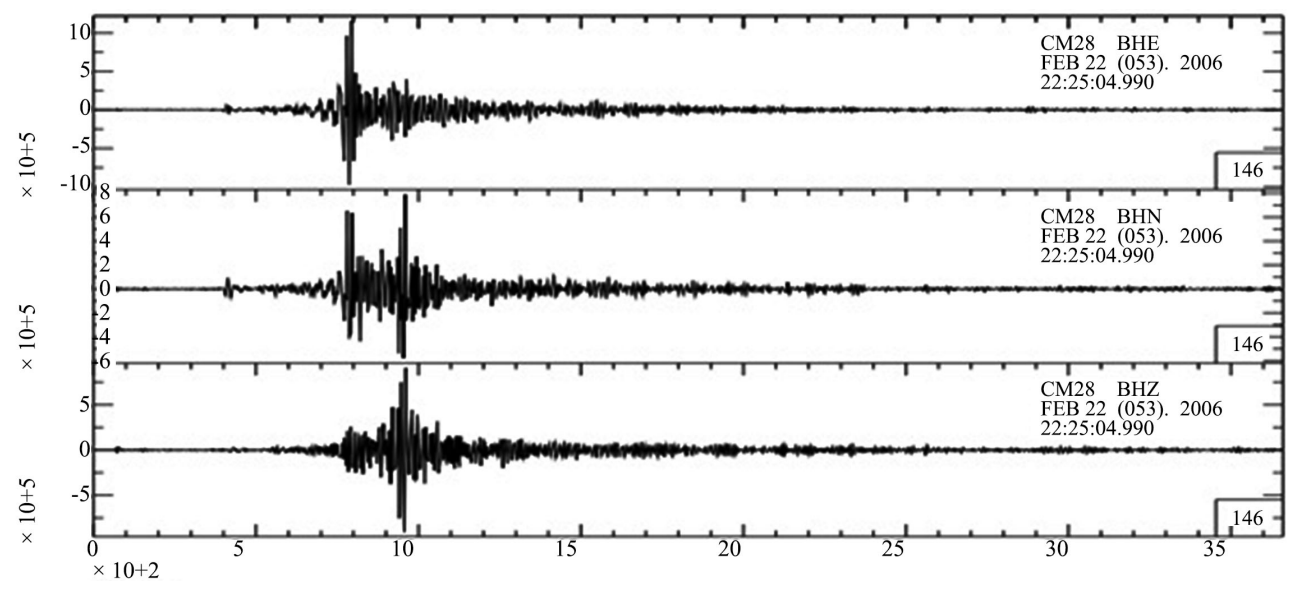

Figure 3. Example of the good seismogram at the station CM28.

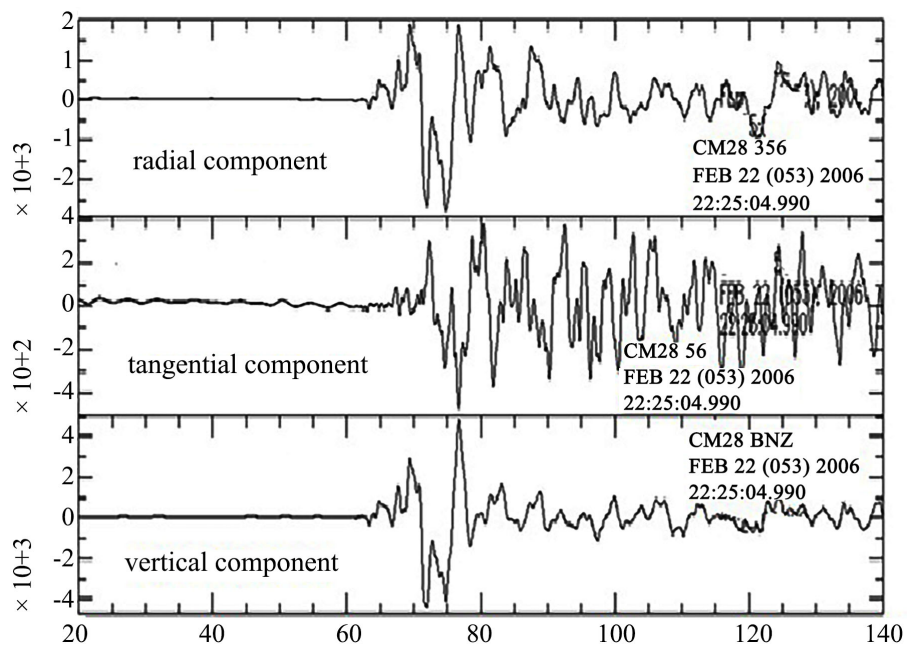

Figure 4. Example of seismogram windowed, filtredand rotated at station CM28.

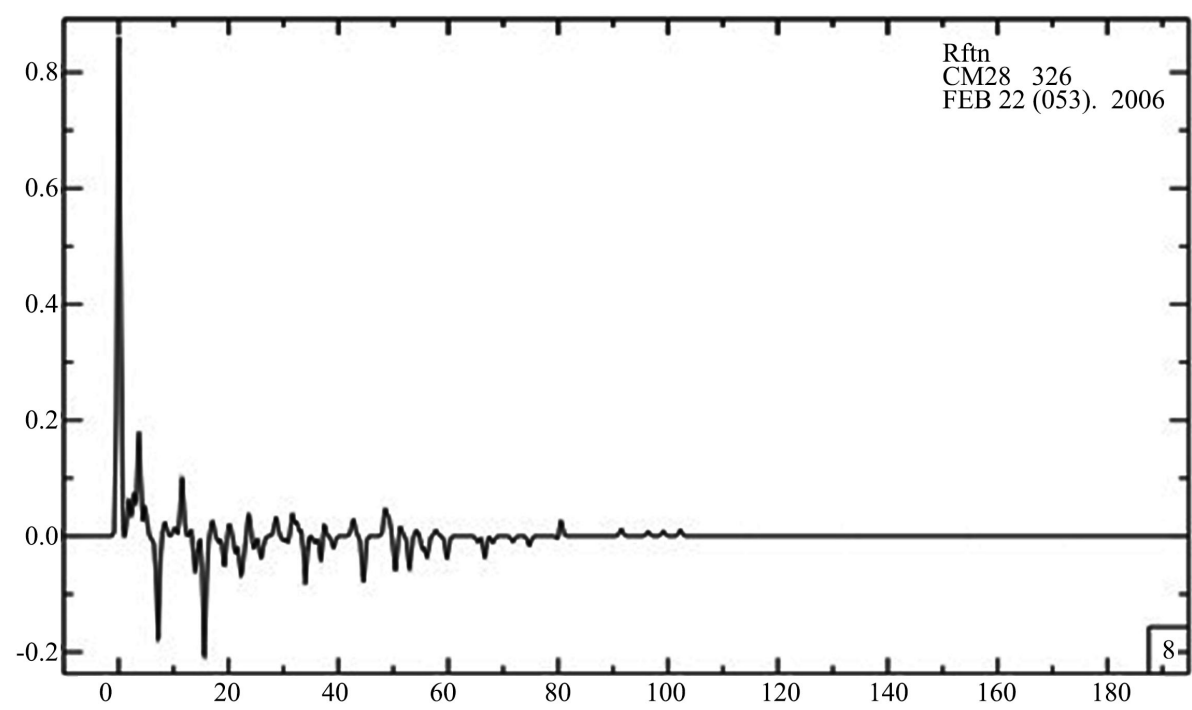

Figure 5. Example of the good receiver function computed at station CM28. The horizontal axis represents the time in second (s) while the vertical axis represents the amplitude of $\mathrm{P}$-wave in millimeter $(\mathrm{mm})$. 


\subsubsection{Inversion of the Receiver Functions}

In this work, the P-waves were inverted to obtain an S-wave velocity model that produces an estimation of shear velocity structure beneath a given seismic station. There is no guarantee that a unique inversion result will be obtained, as the method seeks to minimize the differences between observed and synthetic (or predicted) receiver functions. The inversion was performed using the Rftn96 program developed by [28] and [29]. The method is based on a linearized inversion procedure that minimizes a weighted combination of least squares norms for each data set, a model roughness norm and a vector-difference norm between inverted and pre-set model parameters. The velocity models obtained are consequently a compromise between fitting the observations, model simplicity and a priori constraints. The velocity models are associated at the synthetic receiver functions. Synthetic seismograms are generated using a fast three dimension ray tracing scheme based on [30]. The earth model is parameterized in terms of constant velocity, planar, dipping layers over half-space. The $\mathrm{P}$ and $\mathrm{S}$ wave velocities, density, strike and dip angles, and thickness are specified for each layer in the model. Synthetic vertical radial and transverse seismograms are generated by specifying a back azimuth and ray parameter for the plan of P-wave incident at the base of the model. The starting model used in this inversion consisted of an isotropic medium of constant velocity layers that increase in thickness with depth. The thicknesses of the first, second and third layers are, respectively, $45 \mathrm{~km}, 90 \mathrm{~km}$ and $80 \mathrm{~km}$, while the thickness increases by steeps of $5 \mathrm{~km}$ between 0 and $45 \mathrm{~km}$ depth, by $10 \mathrm{~km}$ between 45 and $135 \mathrm{~km}$ and by $20 \mathrm{~km}$ below the depth of $135 \mathrm{~km}$. Also the linear shear wave velocity increase in the crust from 3.2 to $4.0 \mathrm{~km} / \mathrm{s}$ and from 4 to $4.7 \mathrm{~km} / \mathrm{s}$ in the lithospheric mantle overlying a flattened PREM (Preliminary Reference Earth Model) model [31] for the mantle. Having determined path lengths for each layer, the arrival time for each phase can be calculated. In addition, to the P-arrival and Ps conversions, the synthetic seismogram may include the free-surface multiples associated with each interface.

\section{Results and Discussions}

\subsection{Results}

The different results coming from the inversion of the receiver function computed for the five seismic stations studied are shown in Figure 6 (a, b, c, d and e).

The different interpretations are presented in Table 3 and Table 4.

Regrouping the types and times of different conversions and multiple conversions coming from the curves of synthetic receiver functions from the Garoua rift stations, Table 3 shows that, a good agreement exists between the curves, and the wave has really undergone conversion. The particularity in this area come from the station located in Garoua where, attenuation of the wave starts being observed by the variation of the conversion and the subsequent reverbera- 
tion time and the weakness in the amplitude of the phases which, finally disappear at the station CM32 situated at Maroua. This can be due to inelastic material behavior or internal friction during wave propagation and expresses the heterogeneous character of the crust and anisotropy within the sub-crustal lithosphere of this zone.
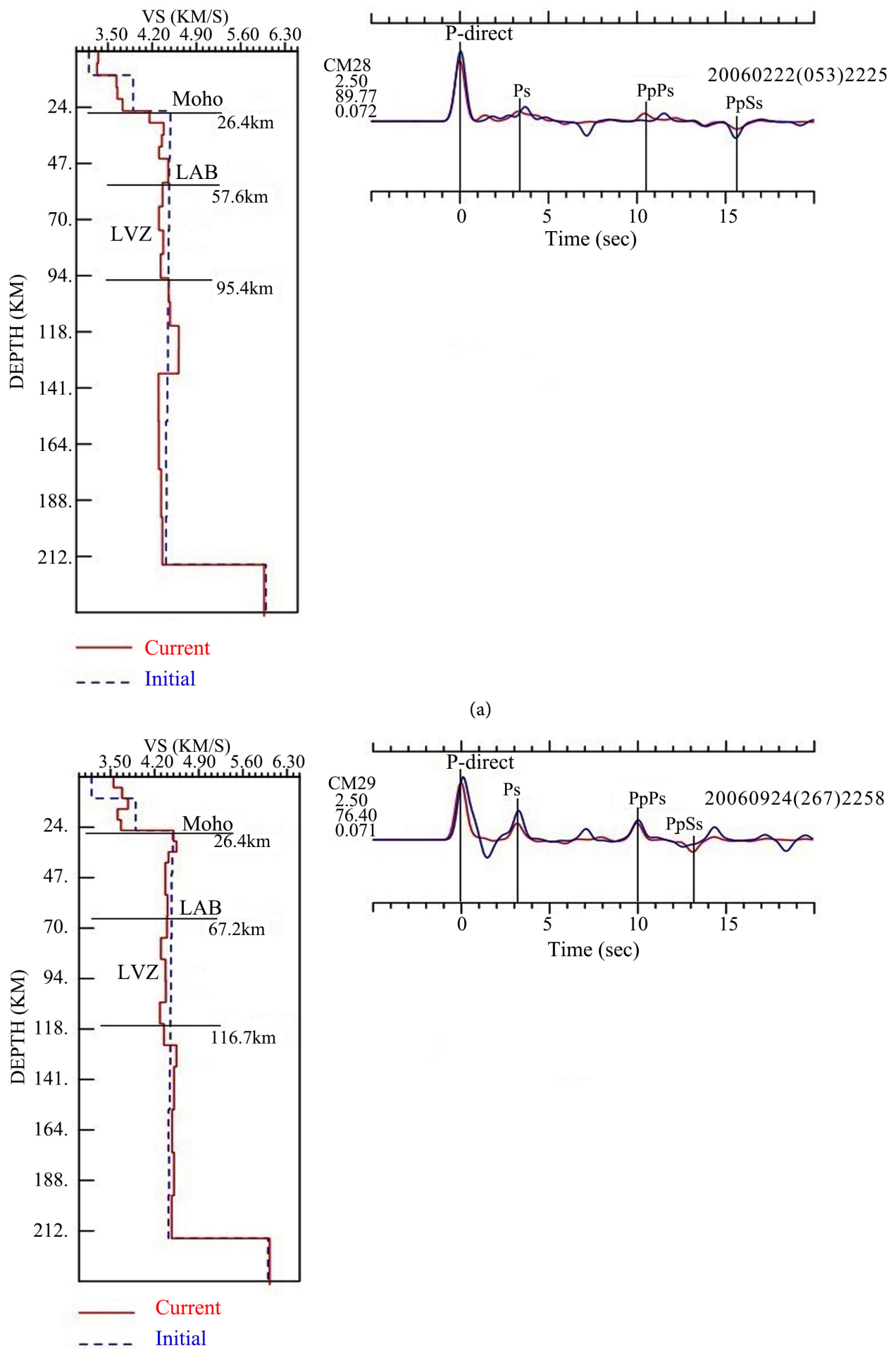

(a)

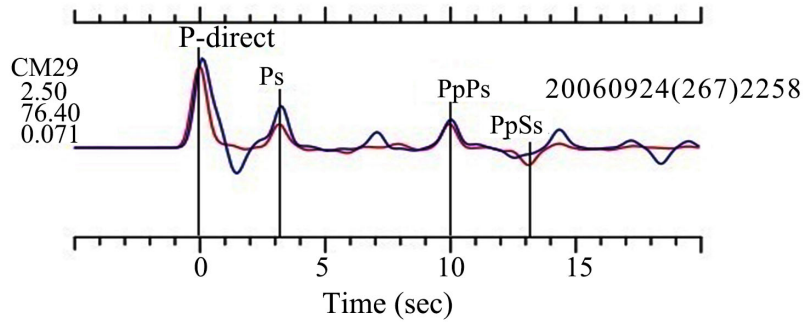

(b) 
VS $(\mathrm{KM} / \mathrm{S})$
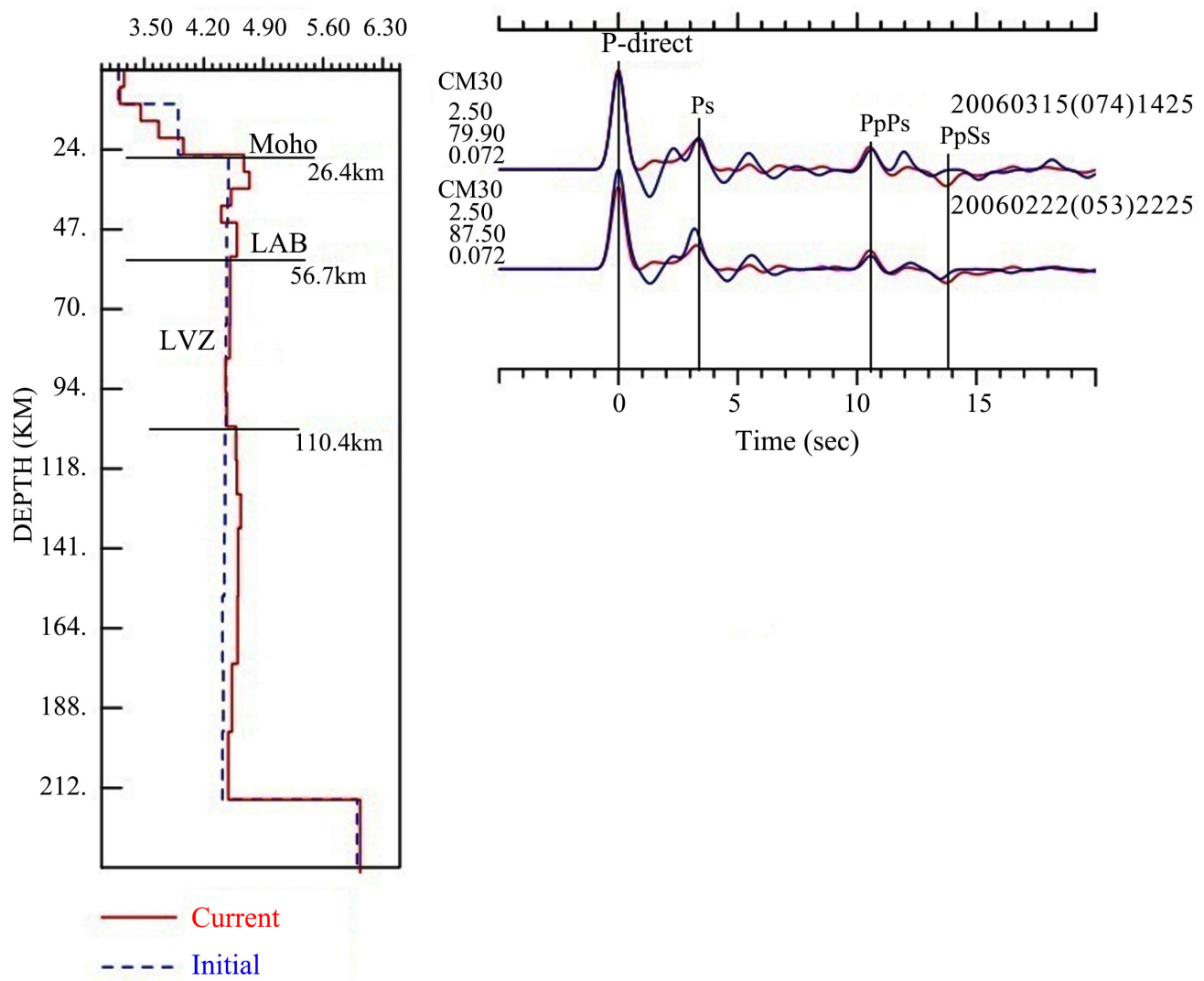

(c)

VS $(\mathrm{KM} / \mathrm{S})$

$\begin{array}{llll}3.20 & 4.00 & 4.80 & 5.60\end{array}$

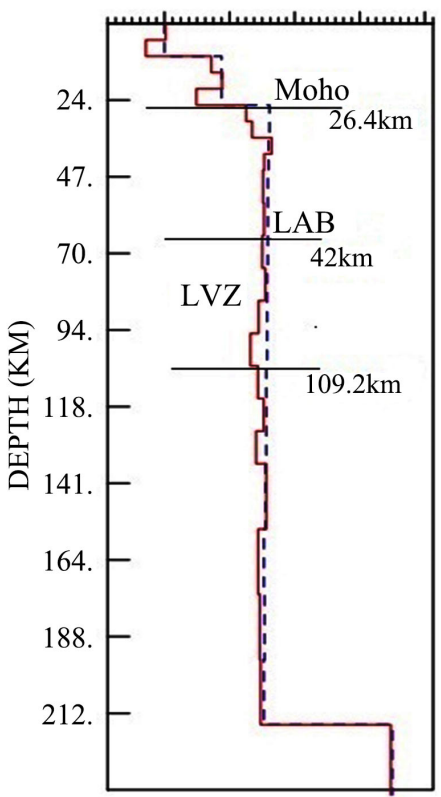

Current

..... Initial

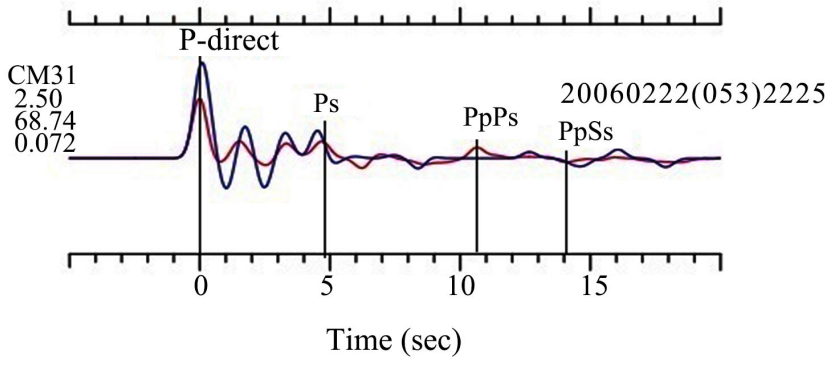

(d) 

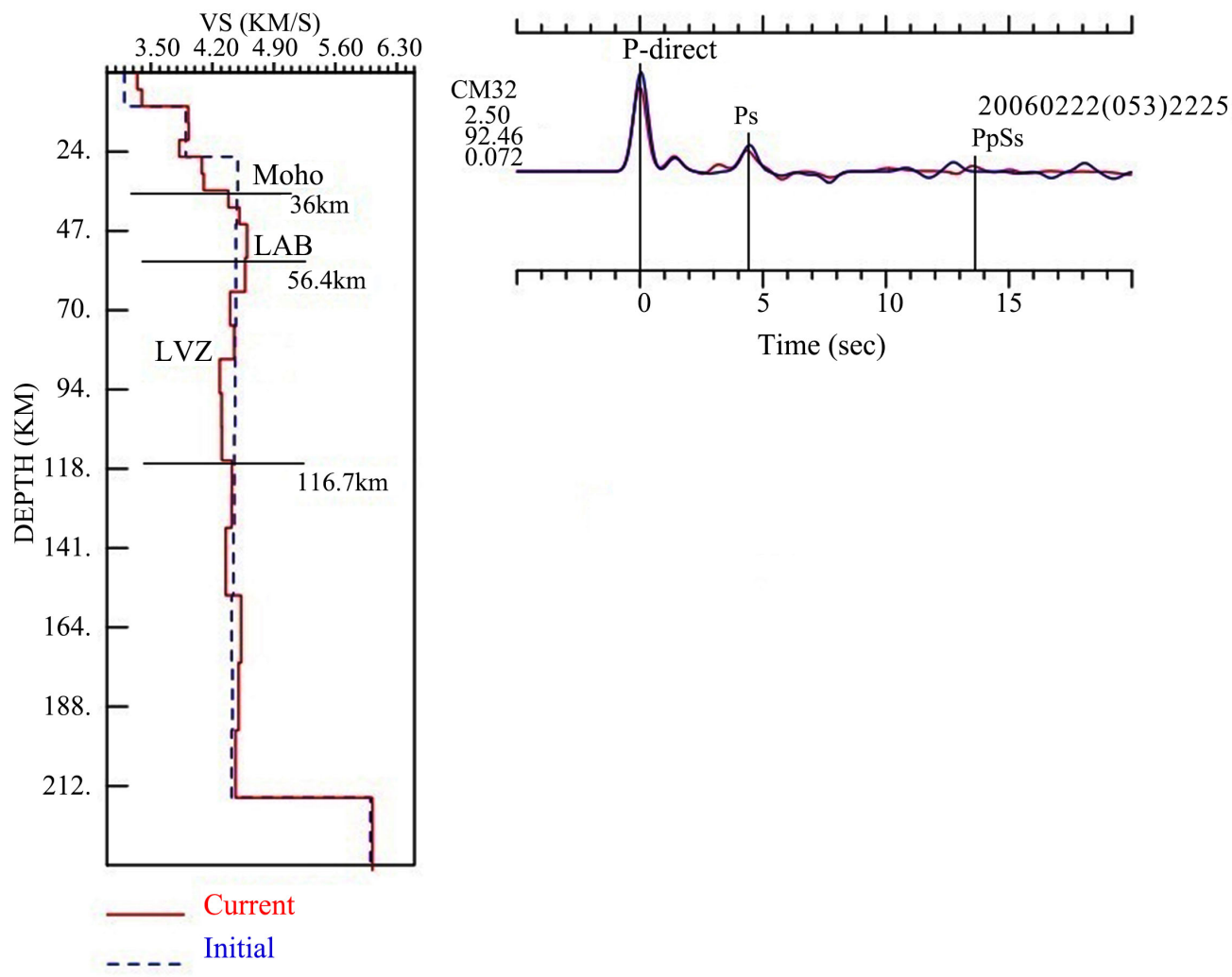

(e)

Figure 6. (a), (b), (c), (d), (e): Shear velocity profiles for Garoua rift region (Cameroon Volcanic Line). Moho: Mohovicic discontinuity; LAB: Lithosphere-Asthenosphere Boundary; LVZ: Low Velocity Zone.

Table 3. Interpretation of the synthetic receiver functions.

\begin{tabular}{cccccc}
\hline Station & Localities & Percent of Signal Power Fit & $\mathrm{t}_{\mathrm{Ps}}(\mathrm{s})$ & $\mathrm{t}_{\mathrm{ppPs}}(\mathrm{s})$ & $\mathrm{t}_{\mathrm{ppss}}(\mathrm{s})$ \\
\hline $\mathrm{CM} 28$ & Poli & 89.77 & 3.2 & 10.5 & 15.5 \\
$\mathrm{CM} 29$ & Garoua & 76.40 & 3.1 & 9.9 & 13 \\
CM30 & Figuil & $79.90 ; 87.50$ & 3.2 & 10.5 & 13.5 \\
CM31 & Yagoua & 68.74 & 4.5 & 10.7 & 18.2 \\
CM32 & Maroua & 92.46 & 4.6 & 13.5 & \\
\hline
\end{tabular}

Table 4. Interpretation of the S-wave velocity profile.

\begin{tabular}{cccccccc}
\hline Station & Localities $\begin{array}{c}\text { Average } \\
\text { crustal Vs } \\
(\mathrm{km} / \mathrm{s})\end{array}$ & $\begin{array}{c}\text { Moho } \\
\text { depth } \\
(\mathrm{km})\end{array}$ & $\begin{array}{c}\text { Thickness } \\
\text { interval of } \\
\mathrm{LVZ}(\mathrm{km})\end{array}$ & $\begin{array}{c}\text { Average } \\
\text { lithospheric } \\
\mathrm{Vs}(\mathrm{km} / \mathrm{s})\end{array}$ & $\begin{array}{c}\text { Average } \\
\text { depth of } \\
\text { lithosphere } \\
(\mathrm{km})\end{array}$ & $\begin{array}{c}\text { Average } \\
\text { lithospheric } \\
\text { mantle } \\
\text { thickness }\end{array}$ \\
\hline CM28 & Poli & 3.7 & 26.4 & $57.6<\mathrm{LVZ}<95.4$ & 3.9 & 57.6 & 31.2 \\
CM29 & Garoua & 4 & 26.4 & $67.2<\mathrm{LVZ}<116.7$ & 4 & 67.2 & 40.8 \\
CM30 & Figuil & 4 & 26.4 & $56.4<\mathrm{LVZ}<110.4$ & 4 & 56.4 & 30 \\
CM31 & Yagoua & 3.6 & 26.4 & $42<\mathrm{LVZ}<109.2$ & 3.7 & 42 & 15.6 \\
CM32 & Maroua & 3.8 & 36 & $56.4<\mathrm{LVZ}<116.7$ & 3.9 & 56.4 & 20.4 \\
\hline
\end{tabular}


The velocity models obtained by inversion of the receiver function followed by the different values coming from Table 4 for the Garoua rift sector allow us to say that the crust is thin with a mean S-waves velocity of the of $3.8 \mathrm{~km} / \mathrm{s}$ and the mean thickness of $28 \mathrm{~km}$ except at Maroua where it is $36 \mathrm{~km}$. While the lithospheric mantle has a mean S-wave velocity of $3.9 \mathrm{~km} / \mathrm{s}$ and its thickness varies between $15.6 \mathrm{~km}$ and $40.8 \mathrm{~km}$. The low velocity zone is located between 42 $\mathrm{km}$ and $116.7 \mathrm{~km}$ of depth and the discontinuities are situated at $26.4 \mathrm{~km}$ of depth for the Moho except for the Maroua station where it is located at $36 \mathrm{~km}$ and between $42 \mathrm{~km}$ and $67.2 \mathrm{~km}$ for the Lithosphere-Asthenosphere Boundary (LAB).

\subsection{Discussions}

\subsubsection{Comparison of the Synthetic Receiver Functions Results by Station and with Previous Estimates}

Observing the different times of Ps phase and subsequent reverberations (PpPs and PpSs) obtained at each station (Table 4), in addition to their different amplitudes, one notes respectively an increase and a decrease from the station CM28 to station CM32. This leads to the deduction that the wave is converted and attenuates according along the South-North direction of the Garoua rift. Previous estimates of the conversion time in the Garoua rift region have been carried out by [25] and the comparison with the new estimates is shown in Table 5 .

Comparing the values of this study with those obtained by [25], one observes that, there is slight difference with respect to the different conversions. This difference can be explained by the method used in computing the same data.

\subsubsection{Comparison of the Shear Wave Velocity Model Results by Locality and with Previous Estimates}

\section{a) Comparison of the shear wave velocity model by locality}

The shear velocity models obtained in each locality present a thin behavior in the crustal part of lithosphere. This behavior is supported by [11] [19] and [22]. The mantle part of the lithosphere is thick, with the depth of the lithosphere that varies beneath the Garoua rift region between $42 \mathrm{~km}$ and $67.2 \mathrm{~km}$ (Figure 7). It comes out again that, the deepest part of the lithosphere is located in the center of the rift (Garoua) and the section having the least depth is located at the North, more precisely in the Yagoua locality (Figure 7).

b) Comparison of the shear velocity model results with previous estimates

Many studies have already been carried out on this behavior and the depth in this area by some geoscientist like [11] [22]. Comparisons with previous estimates of the shear wave velocities as well as with the thickness of the crust and lithosphere are done in Table 6.

Table 6 shows that, estimates of average S-wave velocity (Vs) in the crust are in very good agreement with the previous estimates [22] based on the same seismic data in the Garoua rift region. The main difference between this study and 
previous studies is at the level of the depth of the Moho. This difference comes from the type of data and method used (active data, surface data and geopotential method). On the depth of the lithosphere, no evaluation has been done till date but for one study on the Cameroon volcanic line (covering the Garoua rift region) which situated the depth of the lithosphere to approximately to $60 \mathrm{~km}$ [21]. The lithospheric depth has been determined by the existing of the low velocity zone started at the same depth. This low velocity zone has been confirmed by [23] that found a low-velocity anomaly beneath the CVL extending to at least $300 \mathrm{~km}$ plausibly related to a thermal perturbation.

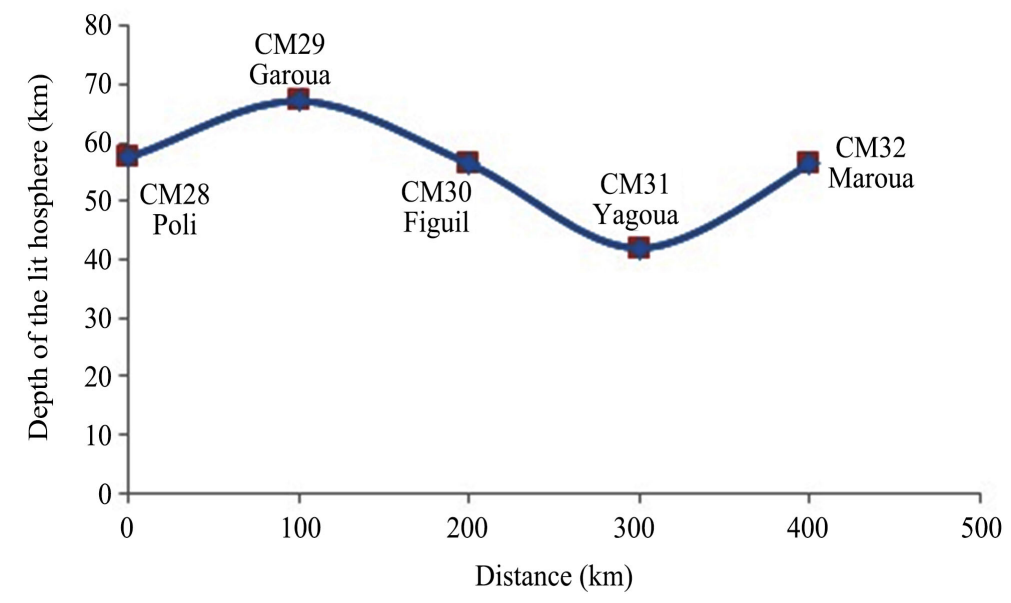

Figure 7. Variation of the depth of lithosphere beneath the Garoua rift region.

Table 5. Comparison of arrival times of the different Ps phases and the subsequent reverberants with those of previous results.

\begin{tabular}{cccccccc}
\hline Region & \multicolumn{2}{c}{$\begin{array}{c}\text { This study by inversion } \\
\text { of the receiver functions }\end{array}$} & \multicolumn{2}{c}{$\begin{array}{c}\text { Other study by stacking } \\
\text { of the receiver function })\end{array}$} & Reference \\
\hline \multirow{2}{*}{ Garoua rift } & $\mathrm{t}_{\mathrm{Ps}}(\mathrm{s})$ & $\mathrm{t}_{\mathrm{PpsP}}(\mathrm{s})$ & $\mathrm{t}_{\mathrm{Ppss}}(\mathrm{s})$ & $\mathrm{t}_{\mathrm{Ps}}(\mathrm{s})$ & $\mathrm{t}_{\mathrm{PpsP}}(\mathrm{s})$ & $\mathrm{t}_{\mathrm{Ppss}}(\mathrm{s})$ & \\
& 3.7 & 11 & 17.6 & 3.2 & 10.5 & 14 & \\
\hline
\end{tabular}

Table 6. Comparing shear velocity model with previous estimates in the Garoua rift.

\begin{tabular}{ccccc}
\hline $\begin{array}{c}\text { Type } \\
\text { of result }\end{array}$ & $\begin{array}{c}\text { This } \\
\text { study }\end{array}$ & $\begin{array}{c}\text { Others } \\
\text { studies }\end{array}$ & $\begin{array}{c}\text { Types of } \\
\text { data used }\end{array}$ & References \\
\hline $\begin{array}{c}\text { Average Vs } \\
\text { of crustal }(\mathrm{km} / \mathrm{s})\end{array}$ & 3.7 & 3.7 & $\begin{array}{c}\text { Seismic } \\
\text { earthquakes }\end{array}$ & {$[22]$} \\
$\begin{array}{c}\text { Average depth } \\
\text { moho }(\mathrm{km})\end{array}$ & 28 & 23 & $\begin{array}{c}\text { Seismic } \\
\text { explosion }\end{array}$ & {$[19]$} \\
& 25.5 & $\begin{array}{c}\text { Gravity } \\
\text { Seismic }\end{array}$ & {$[11]$} \\
$\begin{array}{c}\text { Average depth of } \\
\text { Lithosphere }(\mathrm{km})\end{array}$ & $\begin{array}{c}\text { earthquakes } \\
\text { between }\end{array}$ & & & \\
\hline
\end{tabular}




\section{Conclusion}

Iterative deconvolution has been applied on teleseismic events recorded between 2005 and 2007 to obtain the receiver functions. These receiver functions have been inverted to study the lithosphere-Asthenosphere Boundary beneath the Garoua rift region. It was found from this study that: 1) The synthetic receiver functions associated to the shear velocity model obtained show the existence of a Ps phase and subsequence reverberations PpPs and PpSs at $3.7 \mathrm{~s}, 11 \mathrm{~s}$ and $17.6 \mathrm{~s}$ respectively. The amplitude of the subsequent reverberations decrease and finally disappears at station CM32 passing through stations CM29, CM30 and CM31. The existence of the different phases and the low amplitude of the different phases lead to the deduction that, the wave has really undergone conversion and attenuation along the South-North direction of the Garoua rift region. 2) The lithosphere has a thin nature in its crustal part with the Moho located at a mean depth of $28 \mathrm{~km}$ according to the S-wave velocity of $3.7 \mathrm{~km} / \mathrm{s}$. The lithosphere is thick in its mantle part with its limit depth that varies between $42 \mathrm{~km}$ and 67.2 $\mathrm{km}$ of depth. The deepest part of the lithosphere in the Garoua rift region is situated towards the center that is located around Garoua while the least depth is situated around Yagoua to the North due to the existence of the first low velocity zone (LVZ) in the upper mantle whose thickness also varies between $42 \mathrm{~km}$ and $116.7 \mathrm{~km}$. The different results obtained in this study have been compared to previous results existing in this region. Some similarities have been noticed in some cases like in the velocity of the $\mathrm{S}$ waves in the crust and the time of PpPs phase. The main differences with other results were noticed in the times of Ps and PpSs phases and Moho depth. These differences can be justified by the type of method or data used. In this study, though studies have been carried out on the boundary and the behavior of the lithosphere, it will never the less be important to carry out a study on the origin of the variation noticed in the depth of the lithosphere.

\section{Acknowledgements}

We wish to express our gratitude to the team and sponsor of the Cameroon broadband seismic experiment and particularly to Dr Tokam Kamga Alain who provide the database and the software.

\section{Conflicts of Interest}

The authors declare no conflicts of interest regarding the publication of this paper.

\section{References}

[1] Ligorría, J.P. and Ammon, C.J. (1999) Iterative Deconvolution and Receiver Function Estimation. Bulletin of the Seismological Society of America, 89, 1395-1400.

[2] Elf-Serepca (1981) Service d'Exploration Carte Geologique du Bassin de Garoua.

[3] Regnoult, J.M. (1986) Synthese Géologique du Cameroun. Direction des Mines et 
de la G éologie du Cameroun, Yaounde, 119 p.

[4] Roch, E., Jeremine, E. and Faure Muret, A. (1953) Itineraires géologiques dans le Nord Cameroun et le SW du territoire du Tchad Bull. Service Mines no 1.

[5] Schwoerer, P. (1965) Carte Géologique de Reconnaissance à L’Echelle 1/500000 Notice Explicative sur la Carte Garoua-Est. Direction des Mines et de la Géologie du Cameroun, Yaoundé.

[6] Ndjeng E. (1994) Pole des caractères exoscopiques des grains de quartz des grès de Garoua sur l'interprétation du paloéoenvironnement du bassin de la Bénoué du Crétacé superieur. Ann. Fac. Sci HS Chim. Sci. Nat., 73-82.

[7] Ndjeng, E. and Brunet, M. (1998) Modèle d'évolution géodynamique de deux bassins de l'Hauterivien-Barrémien du Nord-Cameroun: Les bassins de Babouri-Figuil et du Mayo Oulo-Leré (Fossé de la Benoué). Géoscience au Cameroun, 163-165.

[8] Poudjom Djomani, Y.H., Diament, M. and Albouy, Y. (1992) Mechanical Behaviour of the Lithosphere beneath the Adamawa Uplift (Cameroon, West Africa) Based on Gravity Data. Journal of African Earth Sciences, 15, 81-90. https://doi.org/10.1016/0899-5362(92)90009-2

[9] Ngounouno, I., Nkoumbou, C. and Loule, J.P. (1997) Relation entre l'évolution tectono-sédimentaire et le magmatisme du fossé de Garoua (Nord Cameroun). Africa Geoscience Review, 4, 451-460.

[10] Poudjom Djomani, Y.H. and Diament, M. (1992) Modélisation 2-D d'un profil gravimétrique au Cameroun. Stage de fin de première année de Magistère IPGP.

[11] Kamguia, J., Manguelle-Dicoum, E., Tabod, C.T. and Tadjou, J.M. (2005) Geological Models Deduced from Gravity Data in the Garoua Basin, Cameroon. Journal of Geophysics and Engineering, 2, 147-152. https://doi.org/10.1088/1742-2132/2/2/009

[12] Mouzong, M.P., Kamguia, J., Nguiya, S., Shandini, Y. and Manguelle-Dicoum, E. (2014) Geometrical and Structural Characterization of Garoua Sedimentary Basin, Benue Trough, North Cameroon, Using Gravity Data. Journal of Biology and Earth Sciences, 4, E25-E33.

[13] Dorbath, C., Fairhead, J.D. and Stuart, G.W. (1986) A Teleseismic Delay Time Study across the Central African Shear Zone in the Adamawa Region of Cameroon. Geophysical Journal of the Royal Astronomical Society, 86, 751-766. https://doi.org/10.1111/j.1365-246X.1986.tb00658.x

[14] Poudjom Djomani, Y.H. (1993) Apport de la gravimétrie à l'étude de la lithosphère continentale et implications géodynamiques. Etude d'un bombement intraplaque: Le massif de l'Adamaoua (Cameroun). Thèse de Doctorat, Université de Paris-Sud, Orsay.

[15] Poudjom Djomani, Y.H., Diament, M. and Wilson, M. (1997) Lithospheric Structure across the Adamawa Plateau (Cameroon) from Gravity Studies. Tectonophysics, 273, 317-327. https://doi.org/10.1016/S0040-1951(96)00280-6

[16] Noutchogwe, T.C.B. (2004) Apport de la gravimétrie à l'étude de la bordure méridionale du plateau de l'Adamaoua (Cameroun). Thèse de Doctorat 3è cycle Université de Yaoundé I, Cameroon.

[17] Cratchley, C.R., Louis, P. and Ajakaiye, D.E. (1984) Geophysical and Geological Evidence for the Benue-Chad Basin Cretaceous Rift Valley System and Its Tectonic Implications. Journal of African Earth Sciences, 2, 141-150. https://doi.org/10.1016/S0731-7247(84)80008-7

[18] Benkelil, J. (1988) The Origin and Evolution of the Cretaceous Benue Trough (Nigeria). Journal of African Earth Sciences, 8, 251-282. 
https://doi.org/10.1016/S0899-5362(89)80028-4

[19] Stuart, G.W., Fairhead, J.D., Dorbath, L. and Dorbath, C. (1985) A Seismic Refraction Study of the Crustal Structure Associated with the Adamawa Plateau and Garoua Rift, Cameroon, West Africa. Geophysical Journal of the Royal Astronomical Society, 81, 1-12. https://doi.org/10.1111/j.1365-246X.1985.tb01346.x

[20] Kuisseu, T.S., Djieto, L.A.E., Agyingi, C.M., Shandini, Y., Mbohlieu, T.Y. and Ndifor, B.D. (2018) Geometrical Configuration of the Garoua Basin, North Cameroon as Deduced from Earth Gravitational Model (EGM-2008). Anuario do Instituto de Geociencias, 41, 167-176. https://doi.org/10.11137/2018_2_167_176

[21] Fishwick, S. (2010) Surface Wave Tomography: Imaging of the Lithosphere-Asthenosphere Boundary beneath Central and Southern Africa. Lithos, 120, 63-73. https://doi.org/10.1016/j.lithos.2010.05.011

[22] Tokam, A., Tabod, C.T., Nyblade, A.A. and Julià, J. (2010) Structure of the Crust beneath Cameroon, West Africa, from the Joint Inversion of Rayleigh Wave Group Velocities and Receiver Functions. Geophysical Journal International, 183, 1061-1076. https://doi.org/10.1111/j.1365-246X.2010.04776.x

[23] Reusch, A.M., Nyblade, A.A., Wiens, D.A., Shore, P.J., Ateba, B., Tabod, C. and Nnange, J.M. (2010) Upper Mantle Structure beneath Cameron from Body Wave Tomography and the Origin of the Cameroon Volcanic Line. Geochemistry, Geophysics, Geosystems, 11, Q10W07. https://doi.org/10.1029/2010GC003200

[24] Reusch, A.M., Nyblade, A.A., Tibi, R., Wiens, D.A., Shore, P.J., Bekoa, A., Tabod, C.T. and Nnange, J.M. (2011) Mantle Transition Zone Thickness beneath Cameroon: Evidence for an Upper Mantle Origin for the Cameroon Volcanic Line. Geophysical Journal International, 187, 1146-1150. https://doi.org/10.1111/j.1365-246X.2011.05239.x

[25] Gallacher, R.J. and Bastow, I. (2012) The Development of Magmatism along the Cameroon Volcanic Line: Evidence from Teleseismic Receiver Functions. Tectonics, 31, TC3018. https://doi.org/10.1029/2011TC003028

[26] Pokam, K.S.H., Tabod, C.T., Ndikum, E.N., Tokam, K.A.P. and Gounou, P.B.P. (2018) Thickness Variations in the Lithospheric Mantle and the Low Velocity Zone of the Adamawa Plateau (Cameroon) from Teleseismic Receiver Functions. Open Journal of Geology, 8, 529-542. https://doi.org/10.4236/ojg.2018.86032

[27] Julià, J. (2007) Constraining Velocity and Density Contrasts across the Crust: Mantle Boundary with Receiver Function Amplitudes. Geophysical Journal International, 171, 286-301. https://doi.org/10.1111/j.1365-2966.2007.03502.x

[28] Julià, J., Ammon, C.J., Herrmann, R.B. and Correig, A.M. (2000) Joint Inversion of Receiver Function and Surface Wave Dispersion Observations. Geophysical Journal International, 143, 99-112. https://doi.org/10.1046/j.1365-246x.2000.00217.x

[29] Julià, J., Ammon, C.J. and Herrmann, R.B. (2003) Lithospheric Structure of the Arabian Shield from the Joint Inversion of Receiver Functions and Surface Wave Group Velocities. Tectonophysics, 371, 1-21. https://doi.org/10.1016/S0040-1951(03)00196-3

[30] Langston, C.A. (1977) Corvallis, Oregon, Crustal and Upper Mantle Structure from Teleseismic P and S Waves. Bulletin of the Seismological Society of America, 67, 713-724.

[31] Dziewonski, A.M. and Anderson, D.L. (1981) Preliminary Reference Earth Model. Physics of the Earth and Planetary Interiors, 25, 297-356.

https://doi.org/10.1016/0031-9201(81)90046-7 